\title{
Littoral Trichoptera of volcanic lakes Vico and Bolsena (Central Italy)
}

\author{
F. Cianficconi*, C. Corallini, F. Tucciarelli
}

Dipartimento di Biologia Animale ed Ecologia, Università, Via Elce di Sotto, 06123 Perugia, Italy.

The first list of Trichoptera from lakes Vico and Bolsena is reported. It is the result of research carried out in 1955 and 19711979 in lake Vico, and in 1957 and 1959-1990 in lake Bolsena. The distribution of caddisflies around the littoral zone depends on the environmental characteristics of the microhabitats. Overall, 16 species from 7 families were collected, 8 of which were found in both lakes, whereas 5 were only collected in Lake Vico, and 3 only occurred in Lake Bolsena. Hydroptila aegyptia and Ecnomus tenellus were the most abundant species in Vico, Tinodes waeneri and T. maclachlani in Bolsena. The trophic categories of the larvae and their gregarines were identified.

Keywords : Trichoptera, checklist, ecology, zoogeography, trophic categories, gregarines.

\section{Introduction}

Information on Trichoptera of volcanic lakes in Lazio derives from a study of Lake Monterosi (Moretti et al. 1967, 1968), from a short paper on Lake Vico (Moretti \& Tucciarelli 1978), and from research carried out on the dietary regime of fish in Lake Bolsena (Gattaponi \& Corallini Sorcetti 1988). The faunistic list of the invertebrate composition in the littoral zone of Lake Vico (Mastrantuono 2000) reported the presence of Trichoptera. Our paper reports findings on Trichoptera collected in Lake Vico (1955, 1971-79) and Lake Bolsena $(1957,1959-90)$ by Moretti, his collaborators and undergraduate students. Examination of aquatic stages and adults, supplemented by ecological, zoogeographical and biological information, led to the compilation of the first checklist of Trichoptera from the two lakes. The specimens were classified by Moretti and they are in the G.P. Moretti Collection in the Dipartimento di Biologia Animale ed Ecologia dell'Università degli Studi di Perugia, Italy.

\footnotetext{
* Corresponding author : E-mail : fernanda@unipg.it
}

\section{Study area, material and methods}

Lake Vico and Lake Bolsena are located in northern Lazio-VT, central Italy (Fig. 1). They differ in altitude

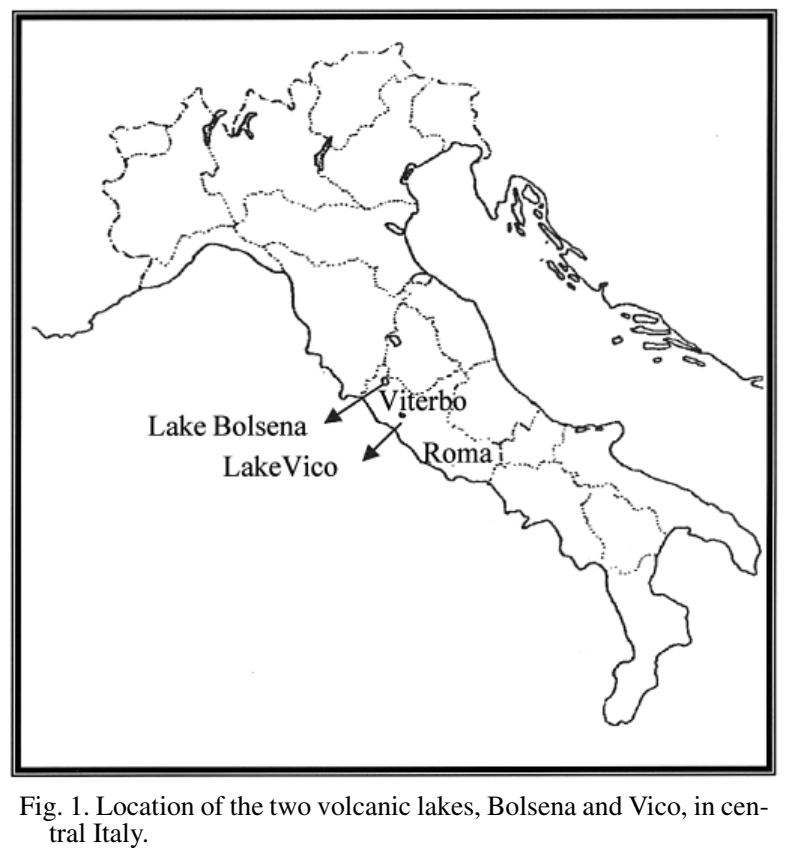


$($ Vico $=510 \mathrm{~m}$ a.s.l.; Bolsena $=305 \mathrm{~m}$ a.s.l. $)$, surface area $\left(\right.$ Vico $=12.08 \mathrm{~km}^{2}$; Bolsena $\left.=113.55 \mathrm{~km}^{2}\right)$, average depth $($ Vico $=21 \mathrm{~m}$; Bolsena $=81 \mathrm{~m})$, and perimeter $($ Vico $=18.8 \mathrm{~km}$; Bolsena $=43 \mathrm{~km})$. Water level depends on the inflow from precipitation and springs and the outflow from Rio Vicano and Fiume Marta. In some zones water is taken for irrigation and some tracts of the perimeter are used for bathing.

Investigation on the Trichopteran fauna was limited to the qualitative composition. For each lake, $21 \mathrm{sam}-$ pling stations were located in the littoral zone to collect aquatic stages (larvae, pre-pupae, pupae) in microhabitats which varied in type of substrate, depth, vegetation (Phragmites australis (Cav.) Steud. and hydrophytes) and in the presence of inlets. Empty cases were also sampled, and they proved the sedimentation of the larval building in the littoral. Adult Trichoptera were collected during the day using kick nets or aspirators in the littoral vegetation and in summer, with light traps in Lake Vico. Samples were taken over one year in different months representatives of the four seasons. The physico-chemical variables were measured for some sample sites.

The dietary regime and symbionts of the larvae were also studied. Larvae of different species, fixed in $4 \%$ formalin, were dissected and the gut contents and symbionts were examined in diluted glycerine under light microscopy.

\section{Results}

The physico-chemical characteristics, derived from the average values of 91 samples in Lake Vico and 76 in Lake Bolsena, were within tolerance limits for littoral Trichopteran larvae ( $\mathrm{pH} 7$ to 7.3 , total hardness 11 to 14 Fr. dgr., $\mathrm{O}_{2} 97$ to $110 \%$, organic matter 2 to 3.6 $\left.\mathrm{mg} / \mathrm{l}^{-1}\right)$. There was no remarkable differences between the two lakes, except for the marsh area of Lake Vico (St. 9) where lower concentrations of $\mathrm{O}_{2}(78.2 \%)$ and higher concentrations of organic matter $\left(8.4 \mathrm{mg} / \mathrm{l}^{-1}\right)$ were registered (Table 1).

The total number of taxa recorded for the two lakes was 16 (15 species, 1 subspecies), belonging to 7 families. Taxa are listed in Tables 2 according to the systematic order of the Italian Trichoptera checklist (Moretti \& Cianficconi 1995). Eight species (Orthotrichia costalis, Oxyethira falcata, Hydroptila aegyptia, Tinodes waeneri, Ecnomus tenellus, Lepidostoma hirtum, Mystacides longicornis, Leptocerus tineiformis) were found in both lakes, 3 (Tinodes maclachlani, Mystacides azurea, Oecetis furva) only occurred in lake Bolsena, and 5 (Hydroptila sparsa, Lype reducta, Agrypnia varia, Limnephilus flavicornis, L. rhombicus reseri) were only collected in lake Vico. In Lake Vico, a total of 149 samples yielded 761 adults $\left(7260^{7}, 35\right.$ O $)$ and 410 aquatic stages. In Lake Bolsena, 151 samples yielded 3278 adults (2232 O’, 1046 O) and 11566 aqua-

Table 1. Mean and standard deviation of variables in each lake (L), and in the stations representative of different microhabitats.

\begin{tabular}{|c|c|c|c|c|c|c|c|c|c|c|}
\hline & $L$ & & & & & Lake V & ico & & & \\
\hline STATIONS & & & 1 & 3 & 7 & & 9 & & 19 & \\
\hline samplings number & 91 & & 17 & 16 & 12 & & 10 & & 11 & \\
\hline air temperature ${ }^{\circ} \mathrm{C}$ & 17 & $( \pm 7.6)$ & $15.9( \pm 7.9)$ & $16.7( \pm 8)$ & 16.3 & $( \pm 7.5)$ & 17.5 & $( \pm 8.3)$ & 16.3 & $( \pm 7)$ \\
\hline water temperature ${ }^{\circ} \mathrm{C}$ & 15.5 & $( \pm 7.5)$ & $15.8( \pm 7)$ & $15.2( \pm 8)$ & 15.4 & $( \pm 7.5)$ & 14 & $( \pm 8)$ & 14.7 & $( \pm 8.6)$ \\
\hline $\mathrm{pH}$ & 7.3 & $( \pm 0.5)$ & $7.2( \pm 0.6)$ & $7.3( \pm 0.5)$ & 7.4 & $( \pm 0.7)$ & 7.6 & $( \pm 0.6)$ & 7 & $( \pm 0.6)$ \\
\hline $\mathrm{O}_{2} \mathrm{mgl}^{-1}$ & 9.5 & $( \pm 3.8)$ & $8.4( \pm 2.5)$ & $10.5( \pm 1.5)$ & 10.5 & $( \pm 1.3)$ & 7.9 & $( \pm 3)$ & 7.4 & $( \pm 4.5)$ \\
\hline $\mathrm{O}_{2}$ saturation $(\%)$ & 97 & $( \pm 27.5)$ & $87( \pm 24)$ & $111( \pm 28)$ & 109 & $( \pm 21)$ & 78.2 & $( \pm 27)$ & 91.5 & $( \pm 41)$ \\
\hline organic matter $\mathrm{mgl}^{-1}$ & 3.6 & $( \pm 2.5)$ & $3.2( \pm 0.8)$ & $2.78( \pm 1)$ & 2.62 & $( \pm 1)$ & 8.4 & $( \pm 5)$ & 3.53 & $( \pm 1.4)$ \\
\hline total hardness Fr.dgr. & 11 & $( \pm 1.5)$ & $11.6( \pm 1)$ & $11.4( \pm 1.3)$ & 11 & $( \pm 1.1)$ & 11.6 & $( \pm 3)$ & 11 & $( \pm 1)$ \\
\hline permanent hardness Fr.dgr. & 4 & $( \pm 1)$ & $4.1( \pm 1)$ & $4.5 \quad( \pm 0.7)$ & 4.6 & $( \pm 1.1)$ & 4 & $( \pm 1.9)$ & 3.8 & $( \pm 1)$ \\
\hline
\end{tabular}

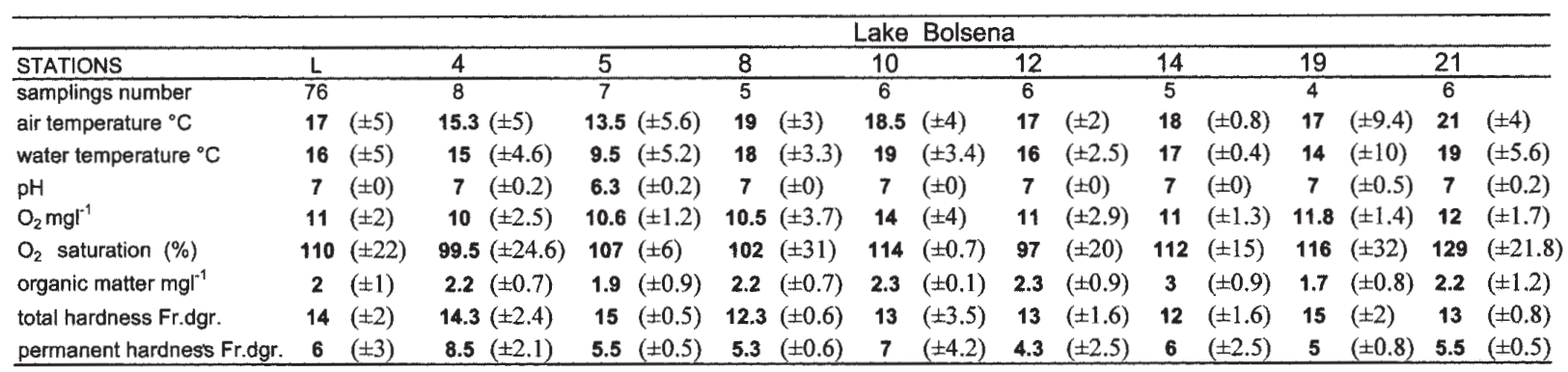




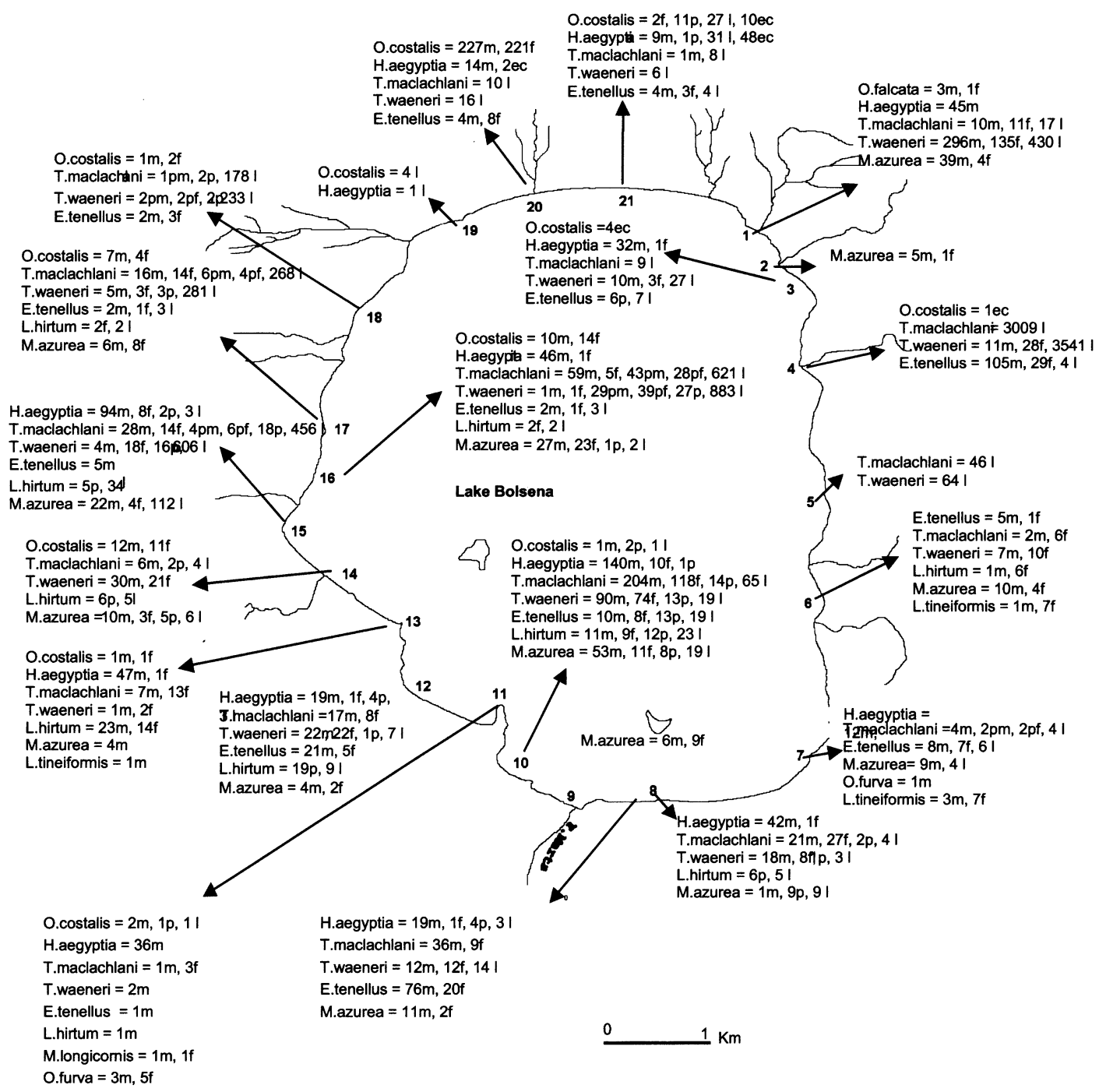

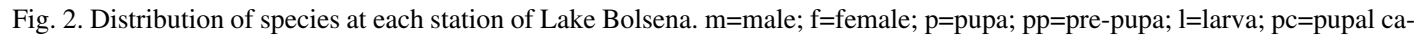
se; ec=empty case.

tic stages. In Lake Bolsena (Fig. 2) all the sampling stations were inhabited by Trichoptera and the species were distributed almost homogeneously around the perimeter. In Lake Vico (Fig. 3), some sampling stations $(2,5,7,8,16,17)$, used for bathing, were uninhabited and the presence of different habitats resulted in non-uniform distributions and a higher number of species. The northern marsh area of this lake was characterized by the presence of large case building larvae (Phryganeidae, Limnephilidae) living in a reed belt. Their empty cases are conveyed to the southern area by the outflow. The species found in the highest num- ber of stations with the highest number of specimens (Table 2) were Hydroptila aegyptia (10 stations, 718 specimens) and Ecnomus tenellus (10 stations, 283 specimens) in Lake Vico; Tinodes waeneri (18 stations, 7111 specimens) and T. maclachlani (17 stations, 5473 specimens) in Lake Bolsena . The majority of the adults belonged to the 5 species listed in Fig. 4, which shows the months of emergence. Ecnomus tenellus (Fig. 5 B) and Hydroptila aegyptia (Fig. 5 C, D) emerged mainly in summer. In Lake Bolsena, Tinodes waeneri had predominantly spring emergence, $T$. $m a$ clachlani (Fig. $5 \mathrm{~A}$ ) predominantly autumnal emergen- 


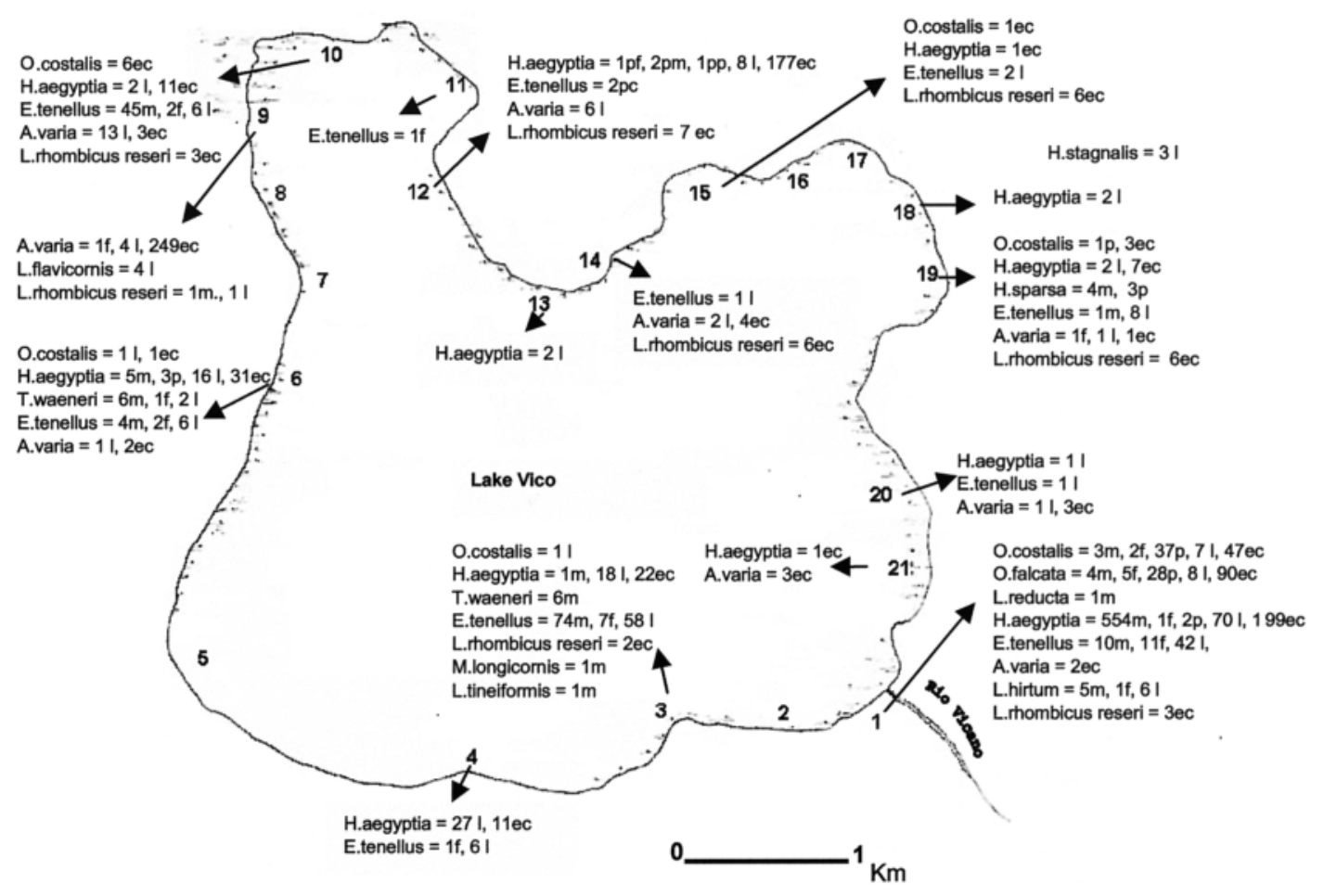

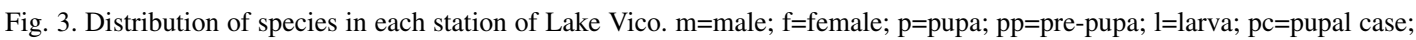
ec=empty case.

ce, and Mystacides azurea (Fig. 5 E) emerged from spring to autumn. For these species, $78 \%$ of the adults were male, (e.g., H. aegyptia 27.08.1975: 3310', 1 우 with light traps).

\section{Discussion}

The Trichoptera fauna of these two lakes is far from being well known. Nevertheless, the present list including 11 species from Lake Bolsena, and 13 species from Lake Vico allowed us to bring out some ecological, biogeographical and biological considerations. Under the ecological perspective, two Trichoptera communities (limnophilous and rheophilous) were identified, confirming previous results from Lake Monterosi (Moretti \& Tucciarelli 1968). The limnophilous species Orthotrichia costalis, Hydroptila aegyptia, Tinodes waeneri, Ecnomus tenellus are well represented in both lakes, as reported in the lacustrian waters of central Italy : Lake Trasimeno (Moretti et al. 1993), Lake Piediluco (Moretti et al. 1981), lakes Lungo and Ripa Sottile (Moretti et al. 1985). Conversely, the leptocerids Mystacides longicornis and Leptocerus tineiformis were sporadically collected ; the first species typically occurs in lakes and ponds of the preAlps and Central Apennines (Moretti et al. 1991), whereas the second species produces consistent populations on the littoral hydrophytes of the lakes in central Italy (Cianficconi et al. 1988). It must be pointed out that Mystacides azurea and Oecetis furva, which are widespread in lentic waters of the Italian Peninsula, were only found in Lake Bolsena. Agrypnia varia, Limnephilus flavicornis, L. rhombicus reseri are exclusive to the marsh area of Lake Vico. The high number (249) of sedimented empty cases of $A$. varia, proved the presence of a large population of this species that is usually uncommon in marsh environments in central Italy (Cianficconi et al. 2000). L. rhombicus reseri was found for the first time in Italy in this lake. Indeed, in 1977, Moretti attributed some specimens from Lake Vico to L. rhombicus n. ssp. because the characteristics of male genitalia (parameres) were different from those of the type species. Afterwards, Malicky (1985) described the subspecies reseri from specimens collected in the Southern Alps. A comparison between the unpublished drawings of Moretti with those of Malicky revealed that the specimens identified as L. rhombi- 
Table 2. List of species and number of specimens found - a s $=$ aquatic stage $;{ }^{\circ}=$ rheophilous species.

\begin{tabular}{|c|c|c|c|c|c|c|c|c|}
\hline \multirow[t]{2}{*}{ TAXA } & \multicolumn{2}{|c|}{ BOLSENA } & \multirow[b]{2}{*}{ as } & \multirow[b]{2}{*}{ Total } & \multicolumn{2}{|c|}{ VICO } & \multirow[b]{2}{*}{ as } & \multirow[b]{2}{*}{ Total } \\
\hline & $\delta$ & 오 & & & $\sigma^{\lambda}$ & 오 & & \\
\hline HYDROPTILIDAE & & & & & & & & \\
\hline 1- Orthotrichia costalis (Curtis, 1834) & 261 & 255 & 47 & 563 & 3 & 2 & 47 & 52 \\
\hline 2- Oxyethira falcata Morton, 1893 & 3 & 1 & & 4 & 4 & 5 & 36 & 45 \\
\hline 3- Hydroptila aegyptia Uimer, 1963 & 555 & 24 & 53 & 632 & 560 & 1 & 157 & 718 \\
\hline 4- Hydroptila sparsa Curtis, $1834^{\circ}$ & & & & & 4 & & 3 & 7 \\
\hline $\begin{array}{l}\text { PSYCHOMYIDAE } \\
\text { 5- Lype reducta (Hagen, 1868)。 }\end{array}$ & & & & & 1 & & & 1 \\
\hline $\begin{array}{l}\text { 5- Lype reducta (Hagen, } 1868)^{\circ} \\
\text { 6- Tinodes maclachlani Kimmins, } 1966^{\circ}\end{array}$ & 412 & 228 & 4833 & 5473 & 1 & & & 1 \\
\hline $\begin{array}{l}\text { 7- Tinodes waeneri (Linnaeus, 1758) } \\
\text { ECNOMIDAE }\end{array}$ & 509 & 337 & 6265 & 7111 & 12 & 1 & 2 & 15 \\
\hline $\begin{array}{l}\text { 8- Ecnomus tenellus (Rambur, 1842) } \\
\text { PHRYGANEIDAE }\end{array}$ & 245 & 86 & 65 & 396 & 134 & 23 & 126 & 283 \\
\hline $\begin{array}{l}\text { 9- Agrypnia varia (Fabricius, 1793) } \\
\text { LIMNEPHILIDAE }\end{array}$ & & & & & & 2 & 28 & 30 \\
\hline 10- Limnephilus flavicornis (Fabricius, 1787) & & & & & & & 4 & 4 \\
\hline $\begin{array}{l}\text { 11- Limnephilus rhombicus reseri Malicky, } 1985 \\
\text { LEPIDOSTOMATIDAE }\end{array}$ & & & & & 1 & & 1 & 2 \\
\hline $\begin{array}{l}\text { 12- Lepidostoma hirtum (Fabricius, } 1775)^{\circ} \\
\text { LEPTOCERIDAE }\end{array}$ & 36 & 33 & 128 & 197 & 5 & 1 & 6 & 12 \\
\hline 13- Mystacides azurea (Linnaeus, 1761) & 201 & 62 & 175 & 438 & & & & \\
\hline 14- Mystacides longicornis (Linnaeus, 1758) & 1 & 1 & & 2 & $\uparrow$ & & & 1 \\
\hline 15- Oecetis furva (Rambur, 1842) & 4 & 5 & & 9 & & & & \\
\hline 16- Leptocerus tineiformis Curtis, 1834 & 5 & 14 & & 19 & 1 & & & 1 \\
\hline Total & 2232 & 1046 & 11566 & 14844 & 726 & 35 & 410 & 1171 \\
\hline
\end{tabular}

LAKE BOLSENA
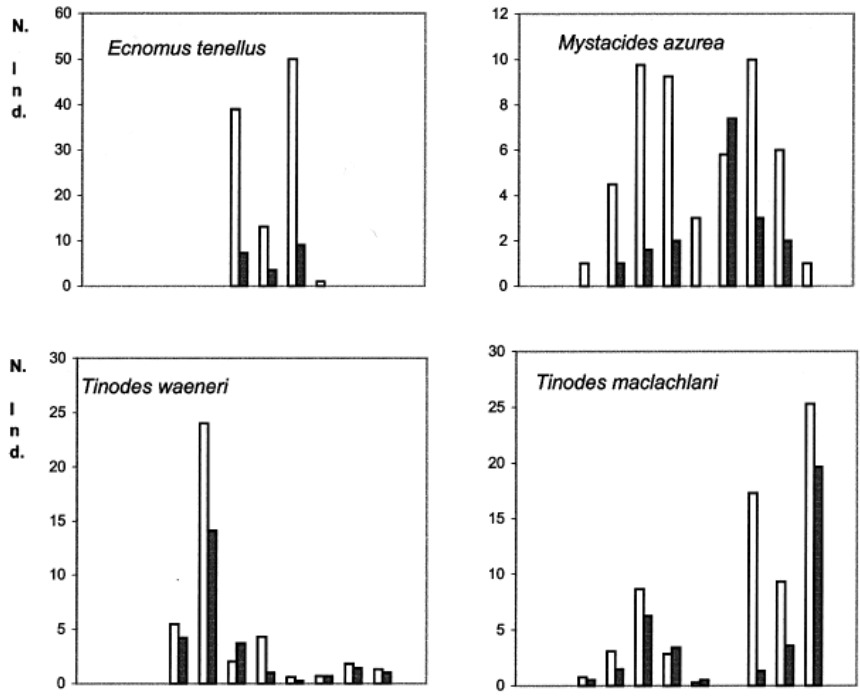

LAKE VICO
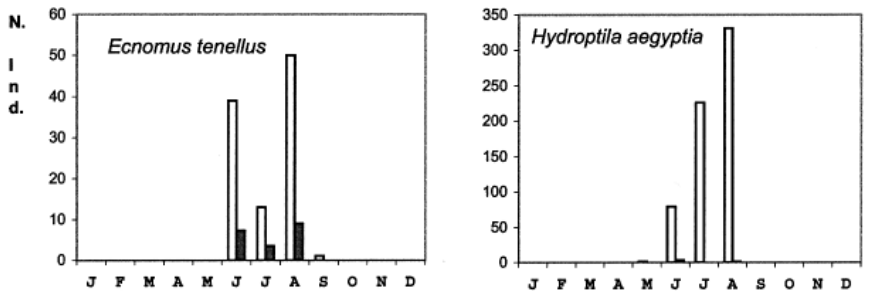

प male - female

Fig. 4. Average monthly emergence of the five most common species 

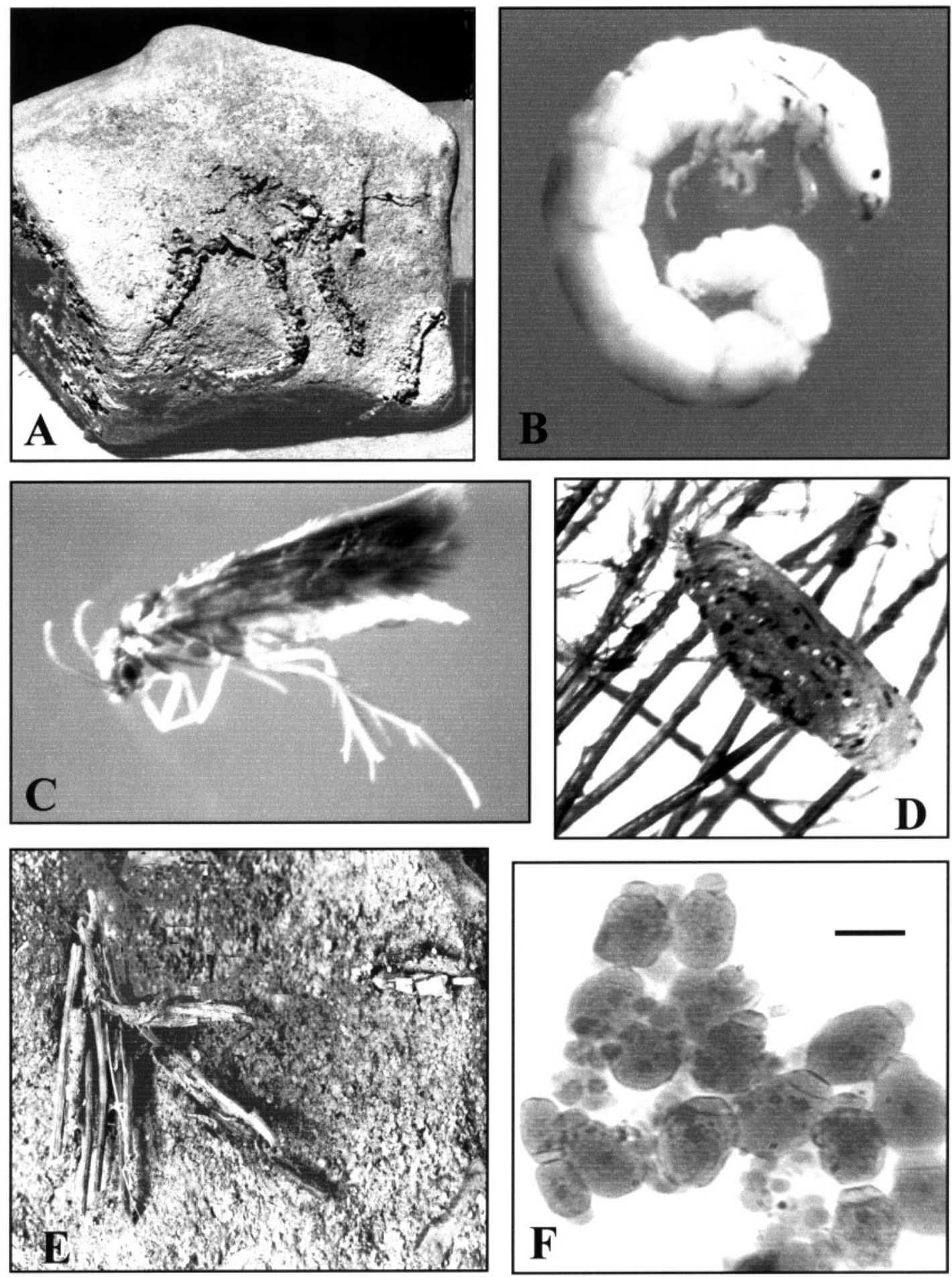

Fig. 5. Some caddisflies from the two lakes. A-Tinodes maclachlani, larval tunnels made of sand (length 15- 20 mm); B-Ecnomus tenellus, larva ( $8 \mathrm{~mm}$ long) extracted from its gallery; C - Hydroptila aegyptia $0^{\prime \prime}(3 \mathrm{~mm}$ long) with pubescent wings; DH. aegyptia larva in its case made of silk encrusted with sand (3.5 mm long) on Ceratophyllum submersum ; E- Mystacides azurea, larval cases (18 $\mathrm{mm}$ long) and pupal cases (10 mm long) on a pebble in lake Bolsena; F- Gregarina pusilla, symbiont of T. maclachlani and T. waeneri, bar $=50 \mu \mathrm{m}$. 


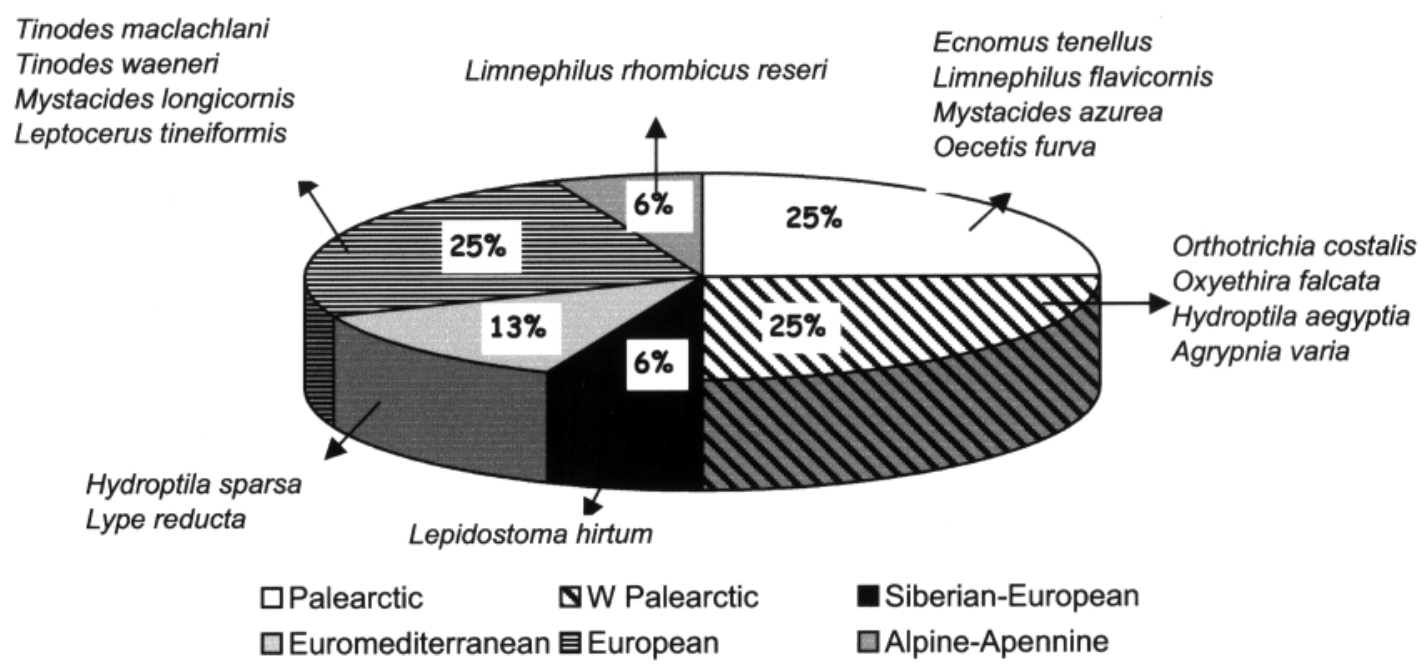

Fig. 6. Chorological categories of species found in lakes Vico and Bolsena.

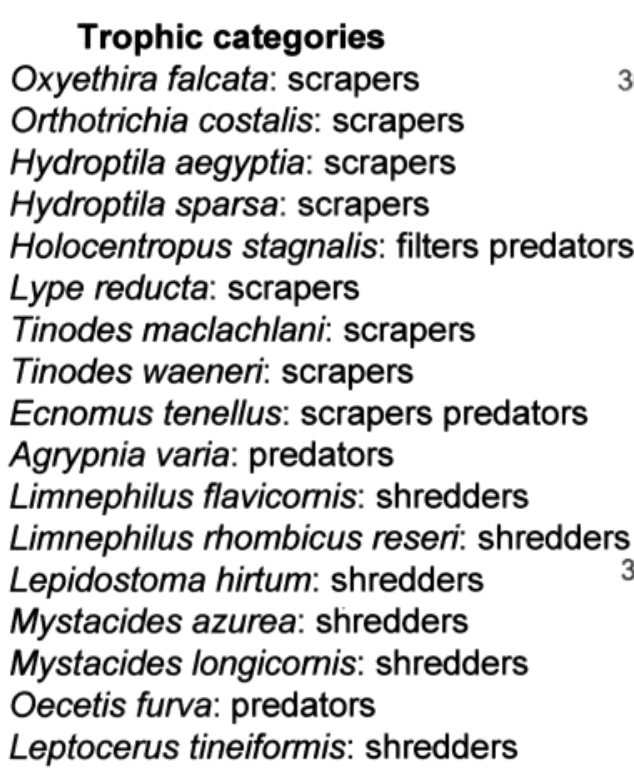

Fig. 7. Percentage of trophic categories in the two lakes

cus $n$. ssp. actually belong to L. rhombicus reseri. Note that larvae of Holocentropus stagnalis (Albarda, 1874), rare in Italy, were found in a drainage pond near Lake Vico. The rheophilous species are represented by : Lype reducta, found near the Rio Vicano, $H y$ droptila sparsa in Lake Vico, but limited to station 19, Tinodes maclachlani in lake Bolsena, in slowly mo-
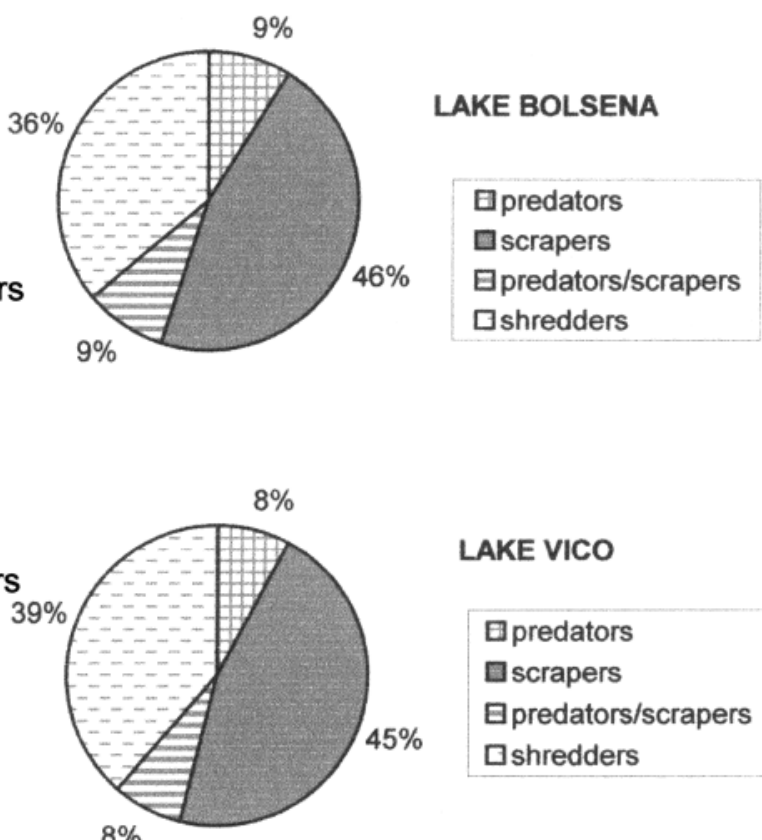

LAKE VICO

Epredators
日scrapers
日predators/scrapers
Qshredders

$8 \%$

ving water between pebbles submerged to a depth of up to $2 \mathrm{~m}$, Lepidostoma hirtum, near the Rio Vicano and along the south-western area of Lake Bolsena. It must be pointed out that $T$. maclachlani lives in hygropetric habitats in Italy (Cianficconi Moretti 1998) and L. hirtum in running waters (Moretti et al. 1997). 
The zoogeographical balance shows the coexistence of different chorological categories with northern distribution. Except for Limnephilus rhombicus reseri which is alpine-appenine, all the species have a wide distribution (4 Palearctic, 4 W-Palearctic, 1 SiberianEuropean, 2 Euromediterranean, 4 European) (Fig.6).

Under the biological perspective, the Trichoptera populations in both lakes belong to the same trophic category with almost identical percentages. The scrapers show the highest percentage, followed by that of the shredders (Fig. 7). The protozoa Gregarina pusilla Baudoin (Fig. $5 \mathrm{~F}$ ) was the only parasite found in the gut of the larvae of Tinodes waeneri (69\% infestation) and T. maclachlani (81\% infestation).

In conclusion, our data show that the littoral zone of two volcanic lakes is very important for Trichoptera coenoses. Nevertheless, in order to have a complete picture of the faunistic composition, additional investigations should be extended to other volcanic lakes of Lazio.

\section{Acknowledgements}

A poster on the Trichopteran fauna of these two lakes was presented at the International Conference -Residence Times in Lakes: Science, Management, Education. Bolsena (Viterbo-Italy) September $29^{\text {th }}$ - October $3^{\text {rd }} 2002$. The authors thank A. Lapini, R.Trippanera, F. Menghini, C. Barbetta, M. Murri for their help in collecting specimens.

\section{References}

Cianficconi F., Corallini C., Mazzerioli S. \& Salerno P. 2000 - Palude di Colfiorito (Umbria, Perugia): i Tricotteri e i loro simbionti (Trichoptera). Boll. Assoc. Romana Entomol., 55, 45-66.

Cianficconi F., Corallini C. \& Moretti G.P. 1998 - Trichopteran fauna of the Italian springs. Pages 125-140 In: Botosaneanu L. (ed.) Studies in crenobiology. Backhuys Publ. Leiden.

Cianficconi F., Corallini Sorcetti C., Pirisinu Q. \& Zaganelli C. 1988 - Ripartizione delle comunità tricotterologiche e coleotterologiche nelle tre isole del Lago Trasimeno. Riv. Idrobiol., 27, 497546.
Cianficconi F., Moretti G.P. \& Q. Pirisinu 1985 - Peuplements lotiques et lénitiques dans le système hydrographique de la Plaine de Rieti (Latium, Italie). Ver. Internat. Verein. Limnol., 22, 33063315.

Gattaponi P. \& Corallini Sorcetti C. 1988. - Regime alimentare di alcune specie ittiche del lago di Bolsena (Viterbo): componente tricotterologica e reperti parassitologici. Riv. Idrobiol., 27, 547-563.

Malicky H., 1985 - Eine neue vikariante von Limnephilus rhombicus Linnaeus 1758 (Trichoptera, Limnephilidae) aus den Südalpen. Mitt. Schewertz Entom. gesell., 58, 315-322.

Mastrantuono L., 2000 - Further data on the invertebrate composition in the littoral of Lake Vico (Central Italy) and trophic evaluation over time. Verh. Internat. Verein. Limnol., 27, 976-980

Moretti G.P. \& Cianficconi F. 1995 - Trichoptera. In: Minelli A., Ruffo S. \& La Posta S. (eds.). Checklist delle specie della fauna italiana, 79, Calderini, Bologna, 155 p.

Moretti G. P., Cianficconi F., Corallini Sorcetti C. \& Boscherini A. 1993 - Fluctuations of Trichoptera populations in Lake Trasimeno (Italy). Pages 223-228 in: Otto C. (ed.) Proceedings 7th International Symposium on Trichoptera, 1992. Backhuys Pub. Leiden..

Moretti G.P., Cianficconi F., Corallini C. \& Tucciarelli F. 1997 -Trichoptera of the River Nera (Central Italy) and symbionts of their larvae. Pages 331-337 in: Holzenthal R.W. \& Flint O.S. (eds.) Proceedings of the 8th International Symposium on Trichoptera. Ohio Biological Survey.

Moretti G.P., Cianficconi F.\& Pirisinu Q. 1968. - Struttura della faunula di Tricotteri del bacino di Monterosi . Boll. Zool., 35, 362

Moretti G.P., Cianficconi F., Pirisinu Q. \& Ponziani G. 1967.- Tricotteri del bacino lacustre di Monterosi (Viterbo). Boll. Zool., 34, 145

Moretti G.P., Cianficconi F., Tomaszewski C. \& Maieki J. 1991. Differences in allometry between Italian and Polish populations of Mystacides longicornis (L.) (Trichoptera). Pages 317-322. in: Tomaszewski C.(ed.). Proceedings of the 6th International Symposium on Trichoptera, Lodz-Zacopane 1989, Adam Michiewicz University Press, Poznan.

Moretti G.P., Cianficconi F., \& Tucciarelli F. 1981 - Ripartizione dei Tricotteri nel sistema idrico del Lago di Piediluco e nella Cascata delle Marmore (Umbria-Terni). Studi trentini di Scienze Naturali. Acta Biol., 58, 315-373.

Moretti G.P. \& Tucciarelli F. 1978. - Rappresentanti rivieraschi della tricotterofauna del lago di Vico (Lazio). Boll. Zool., 45, 37. 

